\title{
The Effects of Exchange Rate on Norway's Bilateral Trade Flow to the UK Via Maritime and Other Transport Modes: Does the 'Marshall-Lerner' Condition Hold?
}

\section{Author(s): Naima Saeed}

Source: Journal of International Logistics and Trade 2020; 18(2):61-76

Published by: Jungseok Research Institute of International Logistics and Trade, Inha University

DOI: https://doi.org/10.24006/jilt.2020.18.2.061

The Journal of International Logistics and Trade is an official journal published by Jungseok Research Institute of International Logistics and Trade, Inha University, Korea. JILT welcomes manuscripts that advance the practice and science of logistics, trade, and other related fields.

Frequency: Quarterly (March, June, September, December)

Stable URL: https://www.ejilt.org

The Jungseok Research Institute of International Logistics and Trade is a specialized academic research institute representing Inha University and the Inha Foundation in Korea. The institute aims to become a representative institute in Northeast Asia in the research of logistics and trade.

Stable URL: https://jrieng.inha.ac.kr

(C) Copyright. Jungseok Research Institute of International Logistics and Trade.

This is an Open-Access article distributed under the terms of the Creative Commons Attribution NonCommercial License (http://creativecommons.org/licenses/by-nc/4.0/) which permits unrestricted noncommercial use, distribution, and reproduction in any medium, provided the original work is properly cited 


\title{
Journal of International Logistics and Trade
}

J. Int. Logist. Trade, 2020, Vol. 18, No. 2, 61-76

pISSN : $1738-2122$ eISSN : 2508-7592

https://doi.org/10.24006/jilt.2020.18.2.061

https://www.ejilt.org

ARTICLE

\section{The Effects of Exchange Rate on Norway's Bilateral Trade Flow to the UK Via Maritime and Other Transport Modes: Does the 'Marshall-Lerner' Condition Hold?}

\author{
Naima Saeed ${ }^{*}$ \\ Department of Working Life and Innovation, School of Business and Law, University of Agder, Kristiansand, Norway
}

$\begin{array}{ll}\text { Received } & \text { February 17, } 2020 \\ \text { Revised } & \text { June 02, } 2020 \\ \text { Accepted } & \text { June 06, } 2020 \\ & \\ & \\ \text { *Corresponding author: Naima Saeed } \\ \text { Department of Working Life and Innovation, } \\ \text { School of Business and Law, University of } \\ \text { Agder, 4604 Kristiansand, Norway } \\ \text { Tel: +47-38142325 } \\ \text { E-mail: naima.saeed@uia.no }\end{array}$

\begin{abstract}
This paper analyzes the impact of macroeconomic variables such as real exchange rate, exchange-rate volatility, and economic growth of the UK and Norway on Norway's bilateral trade flow to the UK via maritime and other transport modes. The first two models considered trade volume (import and export) via only maritime transport, while the third and fourth models considered trade volume via modes other than maritime transport. The empirical validity of the Marshall-Lerner condition is tested to see whether a devaluation of the real exchange rate improves the trade balance in the long term. In addition to the longterm relationship among variables, short-term effects are also evaluated. The results show that the real income of Norway and its trading partner (the UK) is the main determinant of bilateral trade flow via maritime and other transport modes. Moreover, the results indicate that in the long run, the Marshall-Lerner condition is satisfied only for bilateral trade via modes other than maritime transport.
\end{abstract}

Keywords Maritime trade flow, Real exchange rate, Exchange rate volatility, Real income, Autoregressive distributed lag (ARDL) approach, Marshall-Lerner condition

\section{Introduction}

Norway is one of the richest countries in the world, as measured by gross domestic product (GDP) per capita. It has the 34th largest export economy in the world and the 17th most complex economy, according to the economic complexity index (ECI) ${ }^{1}$. According to the International Monetary Fund's world economic outlook database, Norway's total GDP was \$398 billion in 2017. Norway exported $\$ 106 \mathrm{~B}$ and imported $\$ 84.8 \mathrm{~B}$ and achieved a positive trade balance of $\$ 21.2 \mathrm{~B}^{2}$.

Norway's major trading partners are European countries, which receive 80.1 percent of Norwegian exports by value, while 10.2 percent is sold to Asian importers. Norway ships another 5.4 percent to North America, while just 2.3 percent goes to Africa $^{3}$. The United Kingdom is the top export destination of Norway ${ }^{4}$. As for bilateral trade with the UK, the value of Norwegian exports was $\$ 588,538$ million and imports $\$ 407,329$ million in 2016 , according to Statistics Norway ${ }^{5}$. Figure 1 shows the total exports and imports of Norway to and from the UK from the first quarter of 1993 until the 3rd quarter of 2017.

Since Norway's economy depends heavily on oil, the Norwegian krone (NOK) is a vulnerable currency that fluctuates wildly. The exchange-rate fluctuations also affect the competitive positions of different countries. For example, the krone exchange rate influences the demand for Norwegian goods and services, the return on Norwegian financial investments compared to investments in other countries, and domestic inflation via the prices of imports. Since the Norwegian economy is small and very open, the exchange-rate fluctuation is very important for economic development ${ }^{6}$. In this study, the data for a real exchange

\footnotetext{
${ }^{1}$ http://atlas.media.mit.edu/en/profile/country/nor/. Accessed September 5, 2017.

${ }^{2} \mathrm{https} / / /$ atlas.media.mit.edu/en/profile/country/nor/. Accessed September 5, 2018.

${ }^{3} \mathrm{http} / /$ www.worldstopexports.com/norways-top-10-exports/. Accessed September 5,2017.

${ }^{4}$ https://oec.world/en/profile/country/nor/. Accessed September 5,2018.

${ }^{5} \mathrm{http}$ ://www.ssb.no/319702/value-of-external-trade.selected-countries-among-norways-most-important-trade-partners-and-figures-fornorway.usd-million-sy-317. Accessed September 2017.

${ }^{6} \mathrm{http}: / /$ www.norges-bank.no/Upload/import/english/publications/economic_bulletin/2000-04/factorsthat.pdf. Accessed January 5, 2017.
} 


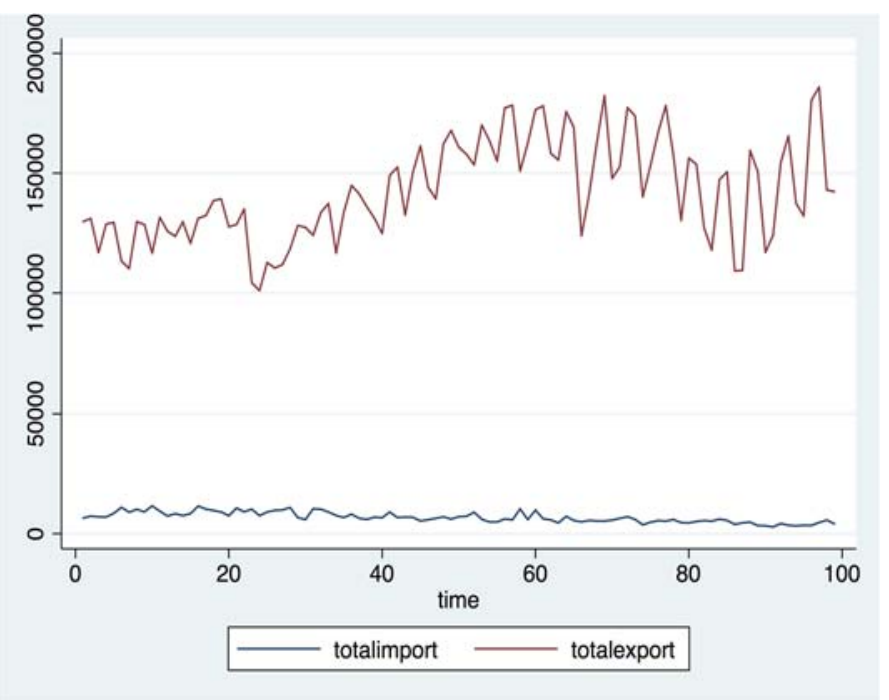

Figure 1. Total exports and imports (tons in 100 thousand) of Norway to and from the UK.

rate and other variables was collected from January 1993 until the third quarter of 2017. The reason for selecting the first quarter of 1993 is that in December 1992, the Central Bank of Norway abandoned the fixed exchange rate in favor of a floating exchange rate, and in January 1993, a royal decree confirmed the floating exchange rate regime (Alstadheim 2016).

This paper analyzes the impact of macroeconomic variables such as real exchange rate, exchange-rate volatility, and the economic growth of the UK and Norway on Norway's bilateral trade flow via maritime and other modes of transport. For international trade, maritime transportation plays a crucial role in Norway. The majority of Norway's foreign trade still passes through seaports (Benito et al. 2003), which is why this study considers two modes of transportation in the analysis. The first model considers trade volume (import and export) via only maritime transport, while the second model includes trade volume via modes other than maritime transport. The empirical validity of the Marshall-Lerner (M-L) condition is tested to see whether a devaluation of the real exchange rate improves the trade balance in the long term. In addition to the long-term relationship among variables, short-term effects are also evaluated. This study applies the autoregressive distributed lag (ARDL) approach (Pesaran et al. 2001).

Several previous studies analyzed the determinants of international trade: see Bahmani-Oskooee and Ardalani (2006), Bahmani-Oskooee and Bolhassani (2014), Barkoulas et al. (2002), Chou (2000), Kavoussi (1984), Klein and Shambaugh (2006), Onafowora (2003), Rose (1991), Srivastava and Green (1986), and Shirvani and Wilbratte (1997). In these studies, to analyze the determinant of international trade, researchers selected a number of variables such as real exchange rate, exchangerate uncertainty, distance, product category, political instability, cultural similarity, colonial past, membership in an economic union, GDP, population, and producer price index. However, except few studies (see for example, Chi 2014, 2016; Coto-Millan et al. 2005, 2011; Lubulwa et al. 2008), these studies did not consider any specific mode of transportation.

Furthermore, very few studies have specifically investigated the effect of macroeconomic variables on demand for maritime transport. Coto-Millán et al. $(2005,2011)$ showed that income has a positive, significant effect on Spain's maritime exports and imports for all types of cargo. Similarly, Lubulwa et al. (2008) found that income has a significant, positive impact on Australia's maritime exports and imports, while the effect of the exchange rate is statistically insignificant. In a recent study, Chi and Cheng (2016) analyzed the short- and long-term impacts of three major macroeconomic variables (real income, bilateral exchange rate, and exchange-rate volatility) on Australia's maritime export flow to its major Asian trading partners. The results showed that Australia's trading partners' real income is the main determinant of maritime export volume, in both the short and long terms. Exchange-rate volatility also appeared to have a significant, long-term effect in the majority of cases.

This study considered four models: export of Norway via maritime and via all other transport modes (including road, rail, and air) in the first and second models, and import of Norway via maritime and other transport modes in the third and fourth models. We then compared macroeconomic variables' effect on maritime trade flow versus trade flow via other modes of transportation. To the best of our knowledge, this paper is the first to examine the effects of three economic variables on the trade flows of Norway to the UK, by two different categories of transport mode. And the main novelty over other work in this area, for example, Chi and Cheng (2016), Coto-Millán et al. (2005, 2011), and Lubulwa et al. (2008), lies in the testing of the 
empirical validity of the M-L condition to see whether devaluation of the real exchange rate improves the trade balance in the long term via maritime and other transport modes.

The rest of the paper is organized as follows. The next section presents data collection, methodology, and results. Conclusions and discussion are in the subsequent section.

\section{Data collection and methodology}

\subsection{Data collection}

Quarterly data (1993 Q1 to 2017 Q3) for Norway's export and import volumes to and from the UK was collected from the website of Statistics Norway ${ }^{7}$. Quarterly data for the real GDP of Norway and the UK $(2010=100)$ and consumer price index (CPI) was obtained from the Monthly Monetary and Financial Statistics at the Organization for Economic Cooperation and Development (OECD) website. Data for the nominal exchange rate was collected from the website of Norges Bank ${ }^{8}$. The real exchange rates for trading partners were calculated by multiplying the nominal exchange rate by the ratio of the CPI of both countries.

Table 1 presents the descriptive statistics of all the variables used in this study. The exchange-rate volatility is measured by the exponential GARCH (EGARCH). EGARCH extends the classical Generalized Autoregressive Conditional Heteroskedasticity model (GARCH) by correcting the non-negativity constraint and allowing for asymmetries (Brooks 2014).

\subsection{Model}

This study considers the following four models and equations to determine the impact of macroeconomic variables on Norway's trade flow to the UK:

Model 1

$$
\operatorname{InX} X_{(\operatorname{mar}) t}=\alpha_{0}+\alpha_{1} \operatorname{In} Y_{U K(t)}+\alpha_{2} \operatorname{InER} R_{t}+\alpha_{3} \operatorname{In} V_{t}+\varepsilon_{t}
$$

\section{Model 2}

$$
\operatorname{InX} X_{(r e s t) t}=\alpha_{0}+\alpha_{4} \operatorname{In} Y_{U K(t)}+\alpha_{5} \operatorname{InER} R_{t}+\alpha_{6} \operatorname{In} V_{t}+\varepsilon_{t}
$$

\begin{tabular}{|c|c|c|c|c|c|}
\hline Variables & Unit & Mean & Standard deviation & Minimum & Maximum \\
\hline GDP (Norway) & Index $(2010=100)$ & 92.19 & 13.23 & 63 & 113 \\
\hline GDP (UK) & Index $(2010=100)$ & 93.39 & 13.41 & 68 & 115 \\
\hline ER & $\begin{array}{l}\text { NOK against British } \\
\text { pound }\end{array}$ & 11.17 & 1.19 & 9.04 & 13.38 \\
\hline Vol & $\begin{array}{l}\text { Volatility estimate } \\
\text { (EGARCH measure) }\end{array}$ & 1.35 & 0.97 & 0.09 & 3.88 \\
\hline Import via maritime & $\begin{array}{l}\text { Tons } \\
\text { (in } 100 \text { thousand) }\end{array}$ & $6,592.18$ & $2,209.31$ & $2,595.06$ & $11,395.15$ \\
\hline Import via other modes & $\begin{array}{l}\text { Tons } \\
\text { (in } 100 \text { thousand) }\end{array}$ & 215.45 & 76.40 & 86.13 & 372.81 \\
\hline Export via maritime & $\begin{array}{l}\text { Tons } \\
\text { (in } 100 \text { thousand) }\end{array}$ & $67,723.05$ & $28,636.42$ & $43,117.34$ & $330,991.60$ \\
\hline Export via other modes & $\begin{array}{l}\text { Tons } \\
\text { (in } 100 \text { thousand) }\end{array}$ & $79,185.71$ & $25,548.28$ & $44,090.78$ & 264,002 \\
\hline
\end{tabular}

Table 1. Summary statistics for all variables; source: author's compilation

$\overline{\text { GDP, gross domestic product; ER, exchange rate; NOK, Norwegian krone; Vol, volatility; EGARCH, exponential generalized autoregressive }}$ conditional heteroskedasticity.

\footnotetext{
${ }^{7}$ https://www.ssb.no/statistikkbanken/SelectVarVal/Define.asp?MainTable=UhKvTransportLand\&KortNavnWeb=muh\&PLanguage=1\&ch ecked=true. Accessed October 5, 2017.

${ }^{8}$ http://www.norges-bank.no/en/Statistics/exchange_rates/currency/EUR/. Accessed October 5, 2017.
} 
Model 3

$\operatorname{In} M_{(\operatorname{mar}) t}=\alpha_{0}+\alpha_{7} \operatorname{In} Y_{\operatorname{Nor}(t)}+\alpha_{8} \operatorname{InER} R_{t}+\alpha_{9} \operatorname{In} V_{t}+\varepsilon_{t}$

Model 4

$\operatorname{In} M_{(r e s t) t}=\alpha_{0}+\alpha_{10} \operatorname{In} Y_{N o r(t)}+\alpha_{11} \operatorname{InER} R_{t}+\alpha_{12} \operatorname{InV} V_{t}+\varepsilon_{t}$

where

$X_{(\text {mar }) t}=$ the amount of cargo (in tons) shipped via maritime transport from Norway to the UK (exports of Norway) at time period $t$,

$X_{(\text {rest }) t}=$ the amount of cargo (in tons) shipped via other modes from Norway to the UK (exports of Norway) at time period $t$,

$M_{(\text {mar }) t}=$ the amount of cargo (in tons) shipped via maritime transport from the UK to Norway (imports of Norway) at time period $t$,

$M_{\text {(rest)t }}=$ the amount of cargo (in tons) shipped via other modes from the UK to Norway (imports of Norway) at time period $t$,

$Y_{\text {Nor }(t)}=$ the real GDP of Norway,

$Y_{U K(t)}=$ the real GDP of the UK,

$E R_{t}=$ the real bilateral exchange rate between Norway and the UK, and

$\mathrm{V}_{\mathrm{t}}=$ exchange-rate volatility measured by EGARCH.

Regarding the expected signs of coefficients, it is assumed that, $\alpha_{1}, \alpha_{4}, \alpha_{7}$, and $\alpha_{10}>0$, because economic growth in Norway increases the demand for imported goods from the UK (Norwegian imports). Similarly, economic growth in the UK increases the demand for imported goods from Norway (Norwegian exports).

For the bilateral real exchange rate, depreciation of Norwegian currency (a decrease in the value of NOK against the British pound) results in a lower price of imported Norwegian goods in the UK. This lower price causes an increase in demand for Norwegian exports, so the expected signs of $\alpha_{2}$ and $\alpha_{5}$ are positive. A devaluation of Norwegian currency makes the imported products expensive for Norwegian customers, so it is expected that $\alpha_{8}$ and $\alpha_{11}$ are negative. However, the effect of the exchange rate on the trade balance is ambiguous; that is, it could be positive or negative. The positive impact of the exchange rate on the trade balance is because of the "volume effect": with a devaluation of the domestic currency, the increased competitiveness in prices for the domestic country should result in more exports and fewer imports. The negative effect is because of the "import value effect": with a devaluation of the domestic currency, the value of each unit of import also increases, which tends to deteriorate the trade balance (Onafowora 2003). Previous studies showed a mixed effect of the real exchange rate on bilateral trade. For instance, a study conducted by Rose (1991) revealed that the exchange rate did not significantly affect the trade balance, while other studies (see for example, Bahmani-Oskooee and Bolhassani 2014; Klein and Shambaugh 2006; Onafowora 2003; Shirvani and Wilbratte 1997) showed a positive and significant effect of the real exchange rate on bilateral trade. On the other hand, some studies (see for example, Chiu and Ren 2018) identify a negative effect of the depreciation of the real exchange rate on the trade balance. On the basis of this evidence, we expect that $\alpha_{2}, \alpha_{5}, \alpha_{8}$, and $\alpha_{11}$ could be positive or negative.

Exchange-rate volatility can have a positive or negative effect on bilateral trade flow. The negative effect is because of the risk-averse traders who, after witnessing wild swings in the exchange rate, might prefer to decrease trading in the short term until the stability of the exchange rate is restored (Hooper and Kohlhagen 1978). On the other hand, high exchange-rate volatility can also positively affect the export volume, because movements in exchange rates do not just represent a risk, but also create opportunities for economic manufacturers to make profits by utilizing financial innovation tools to effectively avoid exchange-rate risk (De Grauwe 1988; Yuan and Jianxiang 2011). Empirical analysis conducted by previous studies also shows a mixed effect of exchange-rate volatility on bilateral trade. The negative influence on bilateral trade is indicated by the studies conducted by Clark (1973), Clark et al. (2004), Cushman (1986), Ethier (1973), and Perée and Steinherr (1989), while other studies (Broll and Eckwert 1999; Franke 1991; Sercu and Uppal 2003; Sercu and Vanhulle 1992) argue that exchange-rate volatility positively influences the trade balance. Therefore, it is difficult to predict in advance the direction of the effect of exchange-rate volatility on bilateral trade. A number of factors such as the degree of risk aversion of the importers and exporters, the volume of trade, and the availability and depth of hedging mechanisms might affect the actual outcome (Aftab et al. 2017). On the basis of this evidence, we assume that $\alpha_{3}, \alpha_{6}, \alpha_{9}$, and $\alpha_{12}$ could be positive or negative.

\subsubsection{Autoregressive distributed lag model}

When time-series data is used for analysis, the usual properties of the ordinary least-squares estimator (OLS) in a regression 
depend on the assumption that the time-series variables are stationary stochastic processes. A stochastic process (time series) $\mathrm{Y}_{\mathrm{t}}$ is stationary if its mean and variance are constant over time and the covariance between two values from the series only depends on the length of time separating the two values, rather than on the actual time at which the variables are observed (Hill et al. 1997, p. 335). Before applying an OLS regression, we must check if the data is stationary. If nonstationary data will be used to run an OLS regression, it is possible to obtain apparently significant results from unrelated data. Such regressions are said to be spurious (Hill et al. 1997). To avoid spurious regressions, methods other than OLS must be considered. One such approach is an ARDL method (Pesaran et al. 2001).

The ARDL co-integration technique is preferable in the following situations:

1. When dealing with variables that are integrated of a different order: $\mathrm{I}(0), \mathrm{I}(1)$, or a combination of both

2. When there is a single, long-term relationship between the underlying variables in a small sample size

3. When none of the variables is I(2) or higher (Nkoro and Uko 2016; Pesaran and Pesaran 1997)

Equations 1-4 show the long-term relationships among the variables. However, as Bahmani-Oskooee and Ardalani (2006) mentioned, in estimating the long-term relationship, we must consider the short-term dynamics in the estimation procedure. This is achieved by reformulating Equations 1-4 in an error-correction modeling format. Thus, to investigate the short-term and long-term effects of macroeconomic variables on bilateral trade flow via maritime and other modes, we apply ARDL as proposed by Pesaran et al. (2001) and reformulate Equations 1-4 in an error-correction format as follows:

$$
\begin{aligned}
& \Delta \operatorname{InX} X_{(\operatorname{mar}) t}=a_{0}+a_{1} \operatorname{In} X_{(\text {mar }) t-1}+a_{2} \operatorname{In} Y_{U K(t-1)}+a_{3} \operatorname{InER_{t-1}}+a_{4} \operatorname{In} V_{t-1}+\sum_{k=1}^{n} \delta_{k} \Delta \operatorname{In} X_{(\text {mar }) t-k} \\
& +\sum_{k=1}^{n} \rho_{k} \Delta \operatorname{In} Y_{U K(t-k)}+\sum_{k=1}^{n} \lambda_{k} \Delta \operatorname{InER} R_{t-k}+\sum_{k=1}^{n} \varsigma_{k} \Delta \operatorname{In} V_{t-k}+u_{t} \\
& \Delta \operatorname{In} X_{(r e s t) t}=a_{0}+a_{5} \operatorname{In} X_{(r e s t) t-1}+a_{6} \operatorname{In} Y_{U K(t-1)}+a_{7} \operatorname{InE} R_{t-1}+a_{8} \operatorname{In} V_{t-1}+\sum_{k=1}^{n} \emptyset_{k} \Delta \operatorname{In} X_{(r e s t) t-k} \\
& +\sum_{k=1}^{n} \partial_{k} \Delta \operatorname{In} Y_{U K(t-k)}+\sum_{k=1}^{n} \varphi_{k} \Delta \operatorname{InER} R_{t-k}+\sum_{k=1}^{n} \sigma_{k} \Delta \operatorname{In} V_{t-k}+\varepsilon_{t} \\
& \Delta \operatorname{In} M_{(\text {mar }) t}=a_{0}+a_{9} \operatorname{In} M_{(\text {mar }) t-1}+a_{10} \operatorname{In} Y_{N o r(t-1)}+a_{11} \operatorname{InER_{t-1}}+a_{12} \operatorname{In} V_{t-1}+\sum_{k=1}^{n} \omega_{k} \Delta \operatorname{In} X_{(\text {mar }) t-k} \\
& +\sum_{k=1}^{n} \gamma_{k} \Delta \operatorname{In} Y_{N o r(t-k)}+\sum_{k=1}^{n} \vartheta_{k} \Delta \operatorname{InE} R_{t-k}+\sum_{k=1}^{n} \tau_{k} \Delta \operatorname{In} V_{t-k}+\epsilon_{t} \\
& \Delta \operatorname{In} M_{(r e s t) t}=a_{0}+a_{13} \operatorname{In} M_{(r e s t) t-1}+a_{14} \operatorname{In} Y_{N o r(t-1)}+a_{15} \operatorname{InER} R_{t-1}+a_{16} \operatorname{In} V_{t-1}+\sum_{k=1}^{n} \beta_{k} \Delta \operatorname{InX} X_{(r e s t) t-k} \\
& +\sum_{k=1}^{n} \pi_{k} \Delta \operatorname{In} Y_{U K(t-k)}+\sum_{k=1}^{n} \theta_{k} \Delta \operatorname{InE} R_{t-k}+\sum_{k=1}^{n} \eta_{k} \Delta \operatorname{In} V_{t-k}+\xi_{t}
\end{aligned}
$$

where $\Delta$ represents the difference operator; the lag order is expressed as $n$; and $u_{t}, \varepsilon_{t}, \epsilon_{t}$, and $\xi_{t}$ are error terms. The shortterm relationship among the variables is represented by the coefficients following the summation sign $\Sigma$ in Equations 5-8. A long-term co-integration relationship among the variables is expressed by the coefficients $a_{1}-a_{16}$.

\section{Empirical results}

\subsection{Stationary tests}

Since the main assumption of the ARDL approach is that none of the regressor is integrated to order two, I(2), we need to 
conduct a test to check a unit root. The two widely applied unit root tests are the augmented Dickey-Fuller (ADF) test and the Phillips-Perron (PP) test (Dickey and Fuller, 1979; Phillips, 1987; Phillips and Perron, 1988). The main difference between the PP unit root test and the ADF test is in how they deal with serial correlation and heteroskedasticity in the errors. The ADF test uses a parametric autoregression to approximate the autoregressive-moving-average ARMA structure of the errors in the test regression, whereas the PP test ignores any serial correlation in the test regression. The PP test has some advantages over the $\mathrm{ADF}$ test. One advantage is that the PP test is robust to general forms of heteroskedasticity in the error term $u_{t}$. The second advantage is that the user does not have to specify a lag length for the test regression ${ }^{9}$. Because of this, we selected the PP test. In this test, the null hypothesis of a unit root (nonstationary) is tested against the alternative hypothesis of a stationary process.

The graphical presentation of all variables is presented in the figures in the appendix (Figures A1-A8). Since the two variables, the GDPs of the UK and Norway, exhibit a trend, the option "include trend term" is selected while running the PP test. The graph of the variable "exchange-rate volatility" fluctuates (upward and downward) around the zero value, so we selected the option "suppress constant" in the PP test. For all other variables, the constant term is included in the PP test.

Table 2 shows the results of the PP test for all variables. The results indicate that some variables (that is, import via maritime, export via maritime, export via other modes, and exchange-rate volatility) are stationary at level $\mathrm{I}(0)$, while the rest of the variables are integrated at the first difference. In other words, the null hypothesis is not rejected for the level of variables I $(0)$ but is rejected for the first difference.

Although PP has some advantages over ADF, both tests have a common problem: they do not allow for the possibility of a structural break (Waheed et al. 2006). Ignoring a structural break in a unit root test can result in a biased result. For instance, by considering the time of the break as an exogenous phenomenon, Perron (1989) proved that the power to reject a unit root decreases when the stationary alternative is true, and a structural break is ignored. Zivot and Andrews (1992) suggested an alternative of Perron's original test in which they considered that the exact time of the break-point is unknown. The Zivot and Andrews method regards every point as a potential break-date and runs a regression for every possible break-date sequentially (Waheed et al. 2006).

To consider the structural break, in addition to the PP test, we applied the Zivot and Andrews test. The results of the Zivot and Andrews unit root test allowing for a structural break in both intercept and trend are presented in Table 3. The Zivot and Andrews test gives different results than the PP test. According to the Zivot and Andrews test, only two variables (import via maritime transport and income of the UK) are stationary at level, while all other variables are stationary at the first difference. According to both the PP test and the Zivot and Andrews test, none of the variables is integrated at the second difference, I(2). Therefore, all variables can be used to apply the ARDL approach.

Table 2. Phillips-Perron test for unit root

\begin{tabular}{|c|c|c|c|c|c|}
\hline \multirow[b]{2}{*}{ Variables } & \multicolumn{2}{|c|}{ Level I(0) } & \multicolumn{2}{|c|}{ First level I(1) } & \multirow[t]{2}{*}{ Decision } \\
\hline & Z(rho) & $Z(t)$ & Z(rho) & $\mathrm{Z}(\mathrm{t})$ & \\
\hline $\begin{array}{l}\mathrm{In}\left(\mathrm{M}_{\mathrm{mar}}\right)_{\mathrm{t}} \\
\text { (with constant term) }\end{array}$ & $-15.685^{* *}$ & $-2.892^{* *}$ & & & $\mathrm{I}(0)$ \\
\hline $\begin{array}{l}\mathrm{In}\left(\mathrm{M}_{\mathrm{rest}}\right)_{\mathrm{t}} \\
\text { (with constant term) }\end{array}$ & -6.394 & -1.971 & $-120.562^{* * *}$ & $-13.780^{* * *}$ & $\mathrm{I}(1)$ \\
\hline $\begin{array}{l}\operatorname{In}\left(X_{\text {mar }}\right)_{t} \\
\text { (with constant term) }\end{array}$ & $-22.924^{* * *}$ & $-3.648^{* * *}$ & & & $\mathrm{I}(0)$ \\
\hline $\begin{array}{l}\operatorname{In}\left(X_{\text {rest }}\right)_{t} \\
\text { (with constant term) }\end{array}$ & $-28.653^{* * *}$ & $-4.324^{* * *}$ & & & $\mathrm{I}(0)$ \\
\hline $\begin{array}{l}\mathrm{In}\left(\mathrm{Y}_{\mathrm{UK}}\right)_{\mathrm{t}} \\
\text { (with trend) }\end{array}$ & -3.493 & -1.555 & $-100.556^{* * *}$ & $-9.066^{* * *}$ & $\mathrm{I}(1)$ \\
\hline $\begin{array}{l}\text { In }\left(Y_{\text {Norway }}\right) \mathrm{t} \\
\text { (with trend) }\end{array}$ & -7.471 & -3.357 & $-131.873^{* * *}$ & $-15.810^{* * *}$ & $\mathrm{I}(1)$ \\
\hline $\begin{array}{l}\text { In(ER })_{t} \\
\text { (with constant term) }\end{array}$ & -8.458 & -2.073 & $-86.257^{* * *}$ & $-8.375^{* * *}$ & $\mathrm{I}(1)$ \\
\hline $\begin{array}{l}\text { In }(\mathrm{Vol}) \mathrm{t} \\
\text { (constant suppressed) }\end{array}$ & $-14.027^{* * *}$ & $-2.733^{* * *}$ & & & $\mathrm{I}(0)$ \\
\hline
\end{tabular}

${ }^{* *}$ Denotes rejection of the null hypothesis of a unit root at the 5 percent level of significance.

${ }^{* * *}$ Denotes rejection of the null hypothesis of a unit root at the 1 percent level of significance.

${ }^{9} \mathrm{https} / / /$ faculty.washington.edu/ezivot/econ584/notes/unitroot.pdf. Accessed March 2, 2018. 
Table 3. Zivot and Andrews unit root test allowing for structural break in both intercept and trend

\begin{tabular}{|c|c|c|c|}
\hline Variables & $\begin{array}{l}\text { Level I }(0) \\
t \text {-statistic }\end{array}$ & $\begin{array}{c}\text { First level I(1) } \\
\text { t-statistic }\end{array}$ & Decision \\
\hline $\operatorname{In}\left(\mathrm{M}_{\mathrm{mar}}\right)_{\mathrm{t}}$ & $-7.113^{* * *}$ & & $\mathrm{I}(0)$ \\
\hline $\operatorname{In}\left(\mathrm{M}_{\text {rest }}\right)_{\mathrm{t}}$ & -4.113 & $-7.710^{* * *}$ & $\mathrm{I}(1)$ \\
\hline $\operatorname{In}\left(X_{\text {mar }}\right)_{t}$ & -3.978 & $-10.418^{* * *}$ & $\mathrm{I}(1)$ \\
\hline $\operatorname{In}\left(X_{\text {rest }}\right)_{t}$ & -3.555 & -14.133 & $\mathrm{I}(1)$ \\
\hline $\operatorname{In}\left(\mathrm{Y}_{\mathrm{UK}}\right)_{\mathrm{t}}$ & $-6.742^{* * *}$ & & $\mathrm{I}(0)$ \\
\hline $\operatorname{In}\left(Y_{\text {Norway }}\right) t$ & -3.792 & $-10.560^{* * *}$ & $\mathrm{I}(1)$ \\
\hline $\operatorname{In}(E R)_{t}$ & -3.448 & $-8.927^{* * *}$ & $\mathrm{I}(1)$ \\
\hline $\operatorname{In}(\mathrm{Vol})_{\mathrm{t}}$ & -3.526 & $-8.775^{* * *}$ & $\mathrm{I}(1)$ \\
\hline
\end{tabular}

${ }^{* * *}$ Denotes rejection of the null hypothesis of a unit root at the 1 percent level of significance.

t-critical values: $1 \%,-5.57 ; 5 \%,-5.08 ; 10 \%,-4.82$.

\subsection{Test for a structural break}

To check the structural stability in the given model, Pesaran and Pesaran (1997) recommend applying the cumulative sum of recursive residuals (CUSUM) and the CUSUM of squared residuals (CUSUMSQ) proposed by Brown et al. (1975). We apply CUSUM and present the results in Figures A9-A12 (see appendix). The structural stability is confirmed if the plot is confined well within the 5 percent bounds. However, our results (Figures A9-A12) indicate that the plot of CUSUM is not confined within the 5 percent bounds. These results suggest that there is structural instability in all four of our models.

To identify the structural break, we applied a test for a structural break. The results are presented in Table 4 and confirm the following significant structural breaks in each model: in the third quarter of 2012 (Model 1), in the fourth quarter of 1996 (Model 2), in the second quarter of 1997 (Model 3), and in the fourth quarter of 2005 (Model 4). To overcome this problem, we added a dummy variable in each model as an independent variable to balance the residuals.

\subsection{Co-integration}

The next step in the ARDL model is to check the long-term co-integration relationship among the variables. If the results indicate the absence of co-integration, then no long-term stable relationship exists between variables. If the results show cointegration, then a one-way or two-way Granger causality exists in at least the stationary series, and a dynamic specification of the error correction mechanism is appropriate (Engle and Granger 2000).

The null hypothesis of no co-integration is tested against the alternative hypothesis of the presence of a co-integration relationship between the variables. To check the existence of co-integration, we applied a bound test and error-correction term $\left(\mathrm{EC}_{\mathrm{t}-1}\right)$. The null hypothesis of no co-integration relationship is rejected if the values of F-statistics and $\mathrm{t}$-test in the bound test are greater than the critical values and if $\mathrm{EC}_{\mathrm{t}-1}$ is negative and statistically significant in ARDL. The results are presented in Table 5. The results of the bound test show that for all the four models the value of F-statistics is higher than the critical values. However, the results of the t-test indicate that for model 2, the value of the t-test is lower than the critical value, while for the rest of the three models, the values of the $t$-test are greater than the critical values. Since the values of $\mathrm{EC}_{\mathrm{t}-1}$ are negative and statistically significant for the four models, we conclude that there is a long-term stable relationship among the variables. Critical values for Bounds testing are presented in the appendix (Table A1).

\subsubsection{Diagnostic tests}

To confirm the validity of the ARDL approach, diagnostic tests were conducted (Table 6). The Durbin Watson statistic

Table 4. Test for a structural break

\begin{tabular}{|c|c|c|c|c|c|c|c|}
\hline \multicolumn{2}{|c|}{ Model 1} & \multicolumn{2}{|c|}{ Model 2} & \multicolumn{2}{|c|}{ Model 3} & \multicolumn{2}{|c|}{ Model 4} \\
\hline Statistic & $\begin{array}{l}\text { Estimated } \\
\text { break time }\end{array}$ & Statistic & $\begin{array}{l}\text { Estimated } \\
\text { break time }\end{array}$ & Statistic & $\begin{array}{l}\text { Estimated } \\
\text { break time }\end{array}$ & Statistic & $\begin{array}{l}\text { Estimated } \\
\text { break time }\end{array}$ \\
\hline $124.44^{* * *}$ & 2012 Q3 & $91.781^{* * *}$ & 1996 Q4 & $99.658^{* * *}$ & 1997 Q2 & $72.9283^{* * *}$ & 2005 Q4 \\
\hline
\end{tabular}

${ }^{* * *}$ Denotes rejection of the null hypothesis of a unit root at the 1 percent level of significance. 
Table 5. Tests to check co-integration

\begin{tabular}{|c|c|c|c|c|c|}
\hline \multirow[t]{2}{*}{ Models } & \multicolumn{2}{|c|}{ Bounds testing } & \multirow[t]{2}{*}{ Decision } & \multirow[t]{2}{*}{$\mathrm{EC}_{\mathrm{t}-1}$} & \multirow[t]{2}{*}{ Decision } \\
\hline & $F$-statistics & $t$-test & & & \\
\hline Model 1 & $10.469^{* * *}$ & $-7.148^{* * *}$ & Co-integration & $-0.619^{* * *}$ & Co-integration \\
\hline Model 2 & $3.981^{*}$ & -3.358 & Co-integration & $-0.380^{* * *}$ & Co-integration \\
\hline Model 3 & $9.830^{* * *}$ & $-6.894^{* * *}$ & Co-integration & $-0.695^{* * *}$ & Co-integration \\
\hline Model 4 & $5.010^{* *}$ & $-3.797^{*}$ & Co-integration & $-0.339^{* * *}$ & Co-integration \\
\hline
\end{tabular}

Table 6. Diagnostic tests

\begin{tabular}{rcccc}
\hline Models & $\begin{array}{c}\text { Durbin Watson statistic, at } \\
\text { 1st order autocorrelation }\end{array}$ & $\begin{array}{c}\text { Breusch Godfrey (BG) } \\
\text { Lagrange multiplier test for } \\
\text { higher order autocorrelation }\end{array}$ & $\begin{array}{c}\text { Lagrange multiplier (LM) test } \\
\text { for autoregressive conditional } \\
\text { heteroskedasticity }\end{array}$ & $\begin{array}{c}\text { Ramsey Regression } \\
\text { Equation Specification } \\
\text { Error Test (RESET) test }\end{array}$ \\
Model 1 & 2.020 & 0.118 & 2.592 & 1.20 \\
Model 2 & 2.052 & $(0.7316)$ & $(0.1074)$ & 0.87 \\
Model 3 & 2.072 & 0.274 & 0.036 & $(0.4599)$ \\
Model 4 & 1.869 & $(0.6006)$ & $(0.8496)$ & 0.20 \\
& & 0.909 & $(0.3131)$ & $(0.8932)$ \\
\end{tabular}

Note: The values in parenthesis are p-values.

(Durbin and Watson, 1950;1951;1971) is conducted to test for 1st order autocorrelation in the residuals ${ }^{10}$. The results presented in Table 6 show that for Models 1, 2, and 3 the value of the Durbin Watson statistic is slightly greater than 2, while for Model 4 the value is close to 2 . The results confirm that there is no autocorrelation in four models.

The second test is the Breusch Godfrey (BG) Lagrange multiplier (LM) test to check the presence of higher order autocorrelation. The null hypothesis of no higher order autocorrelation is tested against the alternative hypothesis that the residuals are autocorrelated at a higher order. The results indicate that the p-value for all four models is greater than 0.05 . Thus, we accept the null hypothesis of no higher order autocorrelation. The LM test for autoregressive conditional heteroskedasticity (ARCH) proposed by Engle (1982) is commonly applied as a specification test in univariate time series models. The test is conducted to check the null hypothesis of no conditional heteroskedasticity against the alternative hypothesis of an ARCH model. The results of this test show that the p-values in all four models are greater than 0.05 , indicating that heteroskedasticity is not a problem in these models. Finally, the Ramsey Regression Equation Specification Error Test (RESET) test was conducted to test the null hypothesis that the models have no omitted variables. The results show that for all four models the p-value is greater than 0.05 , indicating that there is no omitted variable in the models.

\subsubsection{Long-term estimates}

The following are the long-term estimated equations for the four models:

Model 1

$$
\operatorname{InX} X_{(\operatorname{mar}) t}=4.00^{* * *}+0.904^{* * *} \operatorname{In} Y_{U K(t)}+0.216 \operatorname{InER} R_{t}+0.010 \operatorname{In} V_{t}+D_{1}
$$

where $D_{1}=0$ for $\mathrm{t}<2012 \mathrm{Q} 3$, and $D_{1}=1$ for $\mathrm{t}>2012 \mathrm{Q} 2$,

Model 2

$$
\operatorname{InX} X_{(r e s t) t}=3.294^{* *}+1.049^{* * *} \operatorname{In} Y_{U K(t)}-0.872^{* *} \operatorname{InER} t-0.112^{* * *} \operatorname{In} V_{t}
$$

where $D_{1}=0$ for $\mathrm{t}<1996 \mathrm{Q} 4$, and $D_{1}=1$ for $\mathrm{t}>1996 \mathrm{Q} 3$,

\footnotetext{
${ }^{10}$ The value of the Durbin Watson statistic is always between 0 and 4 . A value near 2 means that there is no autocorrelation in the sample. Values close to 0 show positive autocorrelation, and values approaching 4 indicate negative autocorrelation.
} 
Model 3

$\operatorname{InM}_{(\text {mar }) t}=14.543^{* * *}-2.697^{* * *} \operatorname{In} Y_{\text {Norway }(t)}-0.102 \operatorname{InER} R_{t}-0.002 \operatorname{InV} V_{t}$

where $D_{1}=0$ for $\mathrm{t}<1997 \mathrm{Q} 2$, and $D_{1}=1$ for $\mathrm{t}>1997 \mathrm{Q} 1$,

Model 4

$$
\operatorname{InM}_{(\text {rest }) t}=0.922+1.513^{* *} \operatorname{In} Y_{\text {Norway }(t)}-1.809^{* * *} \operatorname{InER} R_{t}-0.106^{*} \operatorname{InV} V_{t}
$$

where $D_{1}=0$ for $\mathrm{t}<2005 \mathrm{Q} 4$, and $D_{1}=1$ for $\mathrm{t}>2005 \mathrm{Q} 3$.

In this study, we take the log of all variables (dependent and independent variables). Such a model is known as a log-log mode ${ }^{11}$. The results indicate that the most influential variable of Norway's bilateral trade with the UK is the real income. In Models 1 and 2, the GDP of the UK has a positive and significant effect on Norway's exports via maritime and other modes of transport. By comparing Models 1 and 2, the results show that the UK long-term income elasticity for exports of Norway via the other modes of transport is higher than for exports via maritime transport. A 1 percent increase in income in the UK increases Norwegian exports via maritime transport by 90.4 percent and via other modes of transport by 104.9 percent. Similarly, in Models 3 and 4, Norway's real income has a significant impact on Norway's imports from the UK. However, Norway's income has a negative effect on imports via maritime transport while it has a positive effect on imports via other modes.

The results indicate that a 1 percent increase in Norway's income decreases imports via maritime transport by 269.7 percent. One explanation of this unexpected negative sign might be that with the increase in income, consumers in Norway prefer to import products from the UK via transportation modes that are expensive compared to maritime transport but are more flexible and fast, like trucks or air transport. The positive sign of the income elasticity of Norway for import via other modes confirms this explanation. The results show that a 1 percent increase in Norway's income increases Norwegian imports via other modes by 151.3 percent.

The real exchange rate has a negative and significant effect in two models: Model 2 (export via other modes) and Model 4 (import via other modes). However, the results can be used to check the M-L condition. The result of Model 2 shows that with the devaluation of the NOK, that is, when Norwegian products become cheaper for customers in the UK, the demand for Norwegian exports will decrease. The long-term elasticity of the real exchange rate for export via other modes indicates that a 1 percent devaluation in a real exchange rate decreases Norwegian exports by 87.2 percent. One possible explanation of this unexpected sign of the real exchange rate, as explained by Chi (2014), is that with the depreciation of Norwegian currency, Norwegian products become cheap for domestic consumers compared to the same products imported from other countries. As a result, the domestic demand for these products increases, resulting in less export of these products. The result of Model 4 shows that as expected, the devaluation of the NOK (that is when imported products become expensive for Norwegian customers) reduces the demand for imported goods from the UK. However, the long-term elasticity of the real exchange rate for imports via other modes is higher compared to that of export via other modes. A devaluation in the real exchange rate by 1 percent decreases imports by 180.9 percent.

The M-L condition requires that a devaluation of the currency will improve a country's trade balance if the sum of the absolute values of a country's import and export price elasticities are greater than one (Bahmani et al. 2013). In this study, the sum of absolute values of export and import price elasticities is $(0.872+1.809)=2.681$. Although export decreases in response to the devaluation of Norwegian currency, but a decrease in imports is greater than a decrease in export. Thus, we may conclude that the M-L condition is satisfied for bilateral trade via modes other than maritime transport.

The exchange-rate volatility does not have a significant effect on exports and imports via maritime transportation. However, the long-term elasticity of exchange-rate volatility for Norwegian exports and imports via the other modes is negative and significant. Its value is -0.112 , indicating that a 1 percent increase in exchange-rate volatility reduces exports via other modes by 11.2 percent. Similarly, a 1\% increase in exchange-rate volatility decreases imports via other modes by 10.6 percent.

\subsubsection{Short-term estimates}

The following are the short-term estimated equations for the four models:

\footnotetext{
${ }^{11} \mathrm{~A}$ real characteristic of a log-log model is that the coefficients of the independent variables measure the elasticity of the dependent variable with respect to the independent variable; that is, the percentage change in the dependent variable for a given (small) percentage change in the independent variable. The double log transformation gives the estimate of elasticity (Gujarati, 1988).
} 
Table 7. Summary of key determining factors for Norwegian trade to and from the UK

\begin{tabular}{llllll}
\hline \multirow{2}{*}{ Export via maritime } & & Income effects & Exchange rate effects & Volatility effects \\
& Short-term & Positive and significant & Negative and significant & Positive and insignificant \\
& Long-term & Positive and significant & Positive and insignificant & Positive and insignificant \\
Export via rest of & Short-term & Positive and significant & Negative and significant & Negative and significant \\
transport & Long-term & Positive and significant & Negative and significant & Negative and significant \\
Import via maritime & Short-term & Negative and significant & Negative and insignificant & Negative and insignificant \\
& Long-term & Negative and significant & Negative and insignificant & Negative and insignificant \\
Import models via rest of & Short-term & Positive and significant & Negative and insignificant & Negative and significant \\
transport & Long-term & Positive and significant & Negative and significant & Negative and significant \\
\hline
\end{tabular}

Model 1

$\Delta \operatorname{In} X_{(\operatorname{mar}) t}=3.482^{* *} \Delta \operatorname{In} Y_{U K(t)}-0.571^{* *} \Delta \operatorname{InE} R_{t}+0.006 \Delta \operatorname{In} V_{t}$

Model 2

$\Delta \operatorname{In} X_{(\text {rest }) t}=3.274^{* *} \Delta \operatorname{In} Y_{U K(t)}-0.331^{* *} \Delta \operatorname{InER} R_{t}-0.042^{* * *} \Delta \operatorname{In} V_{t}$

Model 3

$\Delta \operatorname{In} M_{(\text {mar }) t}=-1.875^{* * *} \Delta \operatorname{In} Y_{\text {Norway }(t)}-0.071 \Delta \operatorname{InE} R_{t}-0.001 \Delta \operatorname{InV} V_{t}$

Model 4

$\Delta \operatorname{In} M_{(\text {rest }) t}=2.434^{* *} \Delta \operatorname{In} Y_{\text {Norway }(t)}-0.041 \Delta \operatorname{InER} R_{t}-0.036^{* *} \Delta \operatorname{In} V_{t}$

The short-term results are consistent with the long-term results. For instance, the estimated equations indicate that even in the short term the main determinant of bilateral international trade between Norway and the UK is the real income of both countries. It has a positive and significant effect in three models: export via maritime and other modes and import via other modes. For imports via maritime transport, like in the long term, even in the short term, it has a negative effect. The real exchange rate has a negative and significant effect only in Models 1 and 2, indicating that a devaluation of the Norwegian currency reduces Norwegian exports to the UK via maritime and other modes of transport. The exchange-rate volatility has a negative and significant effect in Models 2 and 4, showing that an increase in exchange-rate volatility reduces Norwegian exports and imports to and from the UK via non-maritime modes of transport. Table 7 describes the summary of key determining factors for Norwegian trade to and from the UK.

\section{Conclusion}

This study discusses the effect of three macroeconomic variables - real exchange rate, exchange-rate volatility, and real income - of Norway and the UK on the bilateral trade volume between the countries. It is important to consider the effect of the real exchange rate and exchange-rate volatility on bilateral trade, especially for a small economy like Norway that heavily depends on oil, which makes the NOK a vulnerable currency that wildly fluctuates. The conventional wisdom suggests that the devaluation of the real exchange rate positively affects international trade (M-L condition), while exchange-rate volatility negatively affects it (Hooper and Kohlhagen 1978). However, the empirical analyses conducted by previous studies show mixed results of the effect of these two variables.

The results of this study indicate that in the long run, the devaluation of Norwegian currency against the British pound has a negative and significant effect on Norwegian exports and imports to and from the UK via non-maritime modes of transport. The real exchange rate has insignificant effects on Norwegian exports and imports via maritime transport in the long term; however, in the short term, it has a significant and negative effect on Norwegian exports via maritime and other modes of transport. Thus, we conclude that the traditional version of the M-L condition is sustained in the case of bilateral trade via nonmaritime modes of transport but not in the case of bilateral trade via maritime transport. It is not an excellent policy to devalue the real exchange rate to improve the trade surplus because of the mixed results for different modes of transport. Some previous studies also showed either no support or mixed results for the M-L condition. For instance, Andersen (1993) studied 16 
countries, and the results showed either an insignificant coefficient or one of the unexpected signs for most of the countries. Rose (1991) examined five industrial countries and found a lack of evidence for the M-L condition. Prawoto (2007) analyzed four Asian countries to test the M-L condition. The results revealed that out of the four countries studied, the M-L condition is met for Malaysia and Thailand, but not for Indonesia and Singapore.

In the short and long terms, the real exchange-rate volatility has a negative and significant effect on bilateral trade flow via non-maritime transport modes, supporting the arguments of Clark (1973), Clark et al. (2004), Cushman (1986), Ethier (1973), Hooper and Kohlhagen (1978), and Perée and Steinherr (1989).

This research shows the main determinant of Norway's bilateral trade with the UK is real income, which has a significant effect in all four cases in both the short and long terms. The real income of the UK has a positive and significant effect on Norway's exports via maritime and other modes of transport. Similarly, the real income of Norway has a positive and significant effect on imports via other modes. These results are consistent with the results obtained by Chi and Cheng (2016), Coto-Millán et al. (2005 and 2011), and Lubulwa et al. (2008). However, the results indicate that the real income of Norway has a negative and significant effect on Norwegian imports via maritime transportation. One possible reason for this unexpected negative sign is that with the increase in real income, consumers in Norway prefer to switch to importing via other modes of transport, such as truck or air transport, that, although expensive compared to maritime transport, are flexible and fast. This explanation is confirmed by the positive sign of the income elasticity of Norway for import via the other modes. The limitation of this study is that we have considered only one trading partner of Norway, the UK, for the analysis. In future research, more countries should be included to check whether the real exchange rate's devaluation positively affects the international trade of Norway with the rest of the world.

\section{References}

Alstadheim, R., 2016. Exchange rate regimes in Norway 1816-2016, Norges Bank Staff Memo Report, 15, 1-13.

Aftab, M., Syed, K. B. S, Katper, N. A., 2017. Exchange rate volatility and Malaysian-Thai bilateral industry trade flows. Journal of Economic Studies 44, 99-114.

Andersen, P. S., 1993. The 45-rule revisited. Applied Economics 25, 1279-1284.

Barkoulas, J., Baum, C. F., Caglayan, M., 2002. Exchange rate effects on the volume and variability of trade flows. Journal of International Money and Finance 21, 481-496.

Benito, G. R. G., Berger, E., De La Forest, M., Shum, J., 2003. A cluster analysis of the maritime sector in Norway. International Journal of Transport Management 1, 203-215.

Bahmani, M., Harvey, H., Hegerty, S. W., 2013. Empirical tests of the Marshall-Lerner condition: A literature review. Journal of Economic Studies 40, 411-443.

Bahmani-Oskooee, M., Goswami, G., 2004. Exchange rate sensitivity of Japan's bilateral trade flows. Japan and the World Economy 16, 1-15.

Bahmani-Oskooee, M., Ardalani, Z., 2006. Exchange rate sensitivity of U.S. trade flows: Evidence from industry data. Southern Economic Journal 72, 542-559.

Bahmani-Oskooee, M., Bolhassani, M., 2014. Exchange rate uncertainty and trade between U.S. and Canada: Is there evidence of third-country effect? The International Trade Journal 28, 23-44.

Brooks, C., 2014. Introductory Econometrics for Finance. Cambridge University Press, Cambridge, UK.

Broll, U., Eckwert, B., 1999. Exchange rate volatility and international trade. Southern Economic Journal 66, 178-185.

Brown, R. L., Durbin, J., Evans, J. M., 1975. Techniques for testing the constancy of regression relationships over time. Journal of the Royal Statistical Society 37, 149-163.

Chi, J., 2014. Income and exchange rate sensitivities of cross-border freight flows: Evidence from U.S.-Canada exports and imports by truck, rail, air, and pipeline. Journal of the Transportation Research Forum 53, 59-71.

Chi, J., 2016. Exchange rate and transport cost sensitivities of bilateral freight flows between US and China. Transportation Research Part A: Policy and Practice 89, 1-13.

Chi, J., Cheng, S. K., 2016. Do exchange rate volatility and income affect Australia's maritime export flows to Asia? Transport Policy 47, 13-21.

Chiu, Y. B., Ren, R., 2018. Trade balance, savings rate, and real exchange rate: Evidence from China and its trading partners. Emerging Markets Finance and Trade 55, 351-364.

Chou, W. L., 2000. Exchange rate variability and China's exports. Journal of Comparative Economics 28, 61-79. 
Clark, P. B., 1973. Uncertainty, exchange risk, and the level of international trade. Economic Inquiry 11, 302-313.

Clark, P., Tamirisia, N., Wei, S. J., Sadikov, A., Zeng, L., 2004. Exchange rate volatility and trade flows - some new evidence. IMF Occasional Paper. Available at: http://www.imf.org/external/np/res/exrate/2004/eng/051904.htm

Coto-Millán, P., Baños-Pino, J., Villaverde, J., 2005. Determinants of the demand for maritime imports and exports. Transportation Research Part E: Logistics and Transportation Review 41, 357-372.

Coto-Millán, P., Baños-Pino, J., Sainz-González, R., Pesquera-González, M. Á., Núñez-Sánchez, R., Mateo-Mantecón, I., Hontañón, P. C., 2011. Determinants of demand for international maritime transport: An application to Spain. Maritime Economics and Logistics 13, 237-249.

Cushman, D. O., 1986. Has exchange risk depressed international trade? The impact of third-country exchange risk. Journal of International Money and Finance 5, 361-379.

De Grauwe, P., 1988. Exchange rate variability and the slowdown in growth of international trade. Staff Papers-International Monetary Fund 35, 63-84.

Dickey, D. A., Fuller, W. A., 1979. Distribution of the estimators for autoregressive time series with a unit root. Journal of the American Statistical Association 74, 427-431.

Durbin, J., Watson, G. S., 1950. Testing for serial correlation in least squares regression. I. Biometrika 37, 409-428.

Durbin, J., Watson, G. S., 1951. Testing for serial correlation in least squares regression. II. Biometrika 38, 159-177.

Durbin, J., Watson, G. S., 1971. Testing for serial correlation in least squares regression. III. Biometrika 58, 1-19.

Engle, R. F., 1982. Autoregressive conditional heteroscedasticity with estimates of the variance of United Kingdom inflation. Econometrica 50, 987-1007.

Engle, R. F., Granger, C. W. J., 1991. Long Run Economic Relationships. Oxford University Press, New York, NY.

Ethier, W., 1973. International trade and the forward exchange market. The American Economic Review 63, 494-503.

Franke, G., 1991. Exchange rate volatility and international trading strategy. Journal of International Money and Finance 10, 292-307.

Gujarati, D. N., 1988. Basic Econometrics. McGraw-Hill, Singapore.

Hill, R. C., Griffiths, W. E., Judge, G. G., 1997. Undergraduate Econometrics. John Wiley \& Sons, New York, NY.

Hooper, P., Kohlhagen, S. W., 1978. The effect of exchange rate uncertainty on the prices and volume of international trade. Journal of International Economics 8, 483-511.

Kavoussi, R. M., 1984. Export expansion and economic growth: Further empirical evidence. Journal of Development Economics 4, 241-250.

Klein, M. W., Shambaugh, J. C., 2006. Fixed exchange rates and trade. Journal of International Economics 70, 359-383.

Lubulwa, G., Bolin, R., Slatter, B., Carmody, T., 2008. Container and ship movements through Australian ports: 2007-08 to 2029-30, preliminary estimates. $31^{\text {st }}$ Australian Transport Research Forum, Gold Coast, Australia.

Nkoro, E., Uko, A. K., 2016. Autoregressive Distributed Lag (ARDL) co-integration technique: Application and interpretation. Journal of Statistical and Econometric Methods 5, 63-91.

Onafowora, O., 2003. Exchange rate and trade balance in East Asia: Is there a J-Curve? Economics Bulletin 5, 1-13.

Perée, E., Steinherr, A., 1989. Exchange rate uncertainty and foreign trade. European Economic Review 33, 1241-1264.

Perron, P., 1989. The great crash, the oil price shock and the unit root hypothesis. Econometrica 57, 1361-1401.

Pesaran, M. H., Pesaran, B., 1997. Working with Microfit 4.0: Interactive Econometric Analysis [Windows version]. Oxford University Press, Oxford, UK.

Pesaran, M. H., Shin, Y., Smith, R. J., 2001. Bounds testing approaches to the analysis of level relationships. Journal of Applied Econometrics 16, 289-326.

Phillips, P. C. B., Perron, P., 1988. Testing for a unit root in time series regression. Biometrika 75, 335-346.

Phillips, P. C. B., 1987. Time series regression with a unit root. Econometrica 55, 277-301.

Prawoto, R. B., 2007. Cointegration analysis on trading behavior in four selected Asean countries before monetary crisis. Gadjah Mada International Journal of Business 9, 273-290.

Rose, A. K., 1991. The role of exchange rates in a popular model of international trade: Does the 'Marshall-Lerner' condition hold? Journal of International Economics 30, 301-316.

Sercu, P., Vanhulle, C., 1992. Exchange rate volatility, international trade, and the value of exporting firms. Journal of Banking $\&$ Finance 16, 155-182.

Sercu, P., Uppal, R., 2003. Exchange rate volatility and international trade: A general-equilibrium analysis. European Economic Review 47, 429-441. 
Shirvani, H., Wilbratte, B., 1997. The relationship between the real exchange rate and the trade balance: An empirical reassessment. International Economic Journal 11, 39-50.

Srivastava, R. K., Green, R. T., 1986. Determinants of bilateral trade flows. The Journal of Business, 59, 623-640.

Waheed, M., Alam, T., Ghauri, S. P., 2006. Structural breaks and unit root: Evidence from Pakistan macroeconomic time series. Munich Personal RePEC Archive No. 1797.

Yuan, X., Jianxiang, W., 2011. The Effects of Exchange Rate Volatility on Exports: Evidence from China. International Conference on Management of e-Commerce and e-Government, Hubei, China.

Zivot, E., Andrews, D. W. K., 1992. Further evidence on the great crash, the oil price shock and the unit root hypothesis. Journal of Business and Economic Statistics 10, 251-270. 


\section{Appendix}

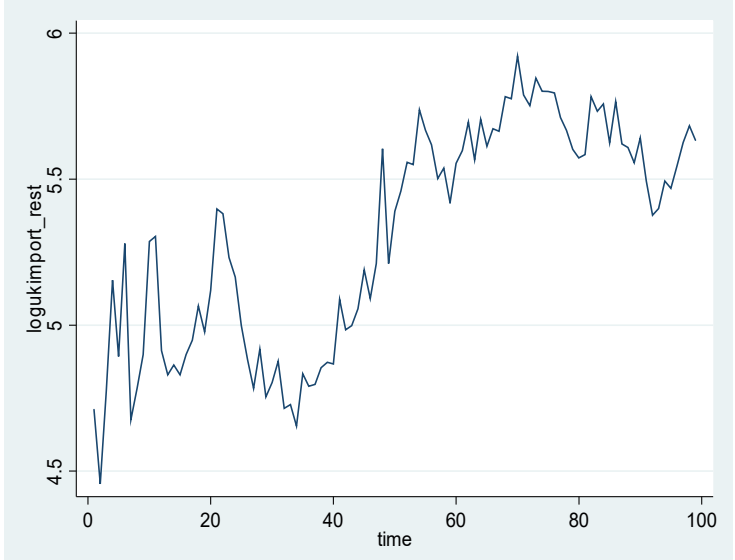

Figure A1. Imports of Norway via other transport modes.

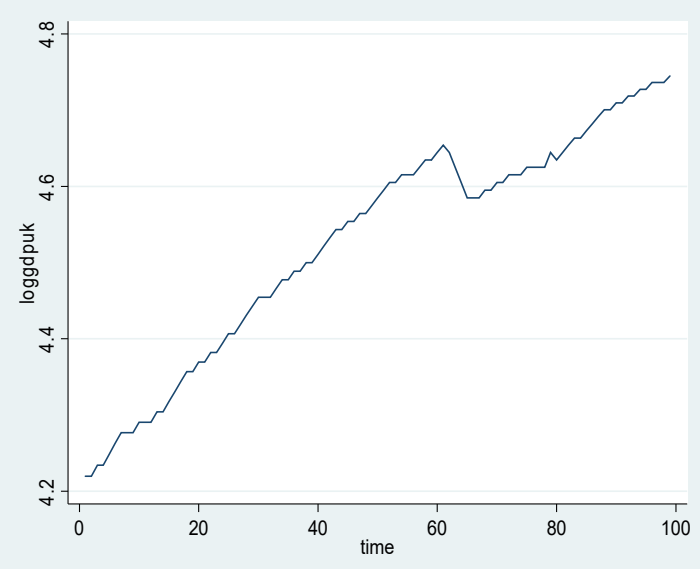

Figure A3. Real income of the UK.

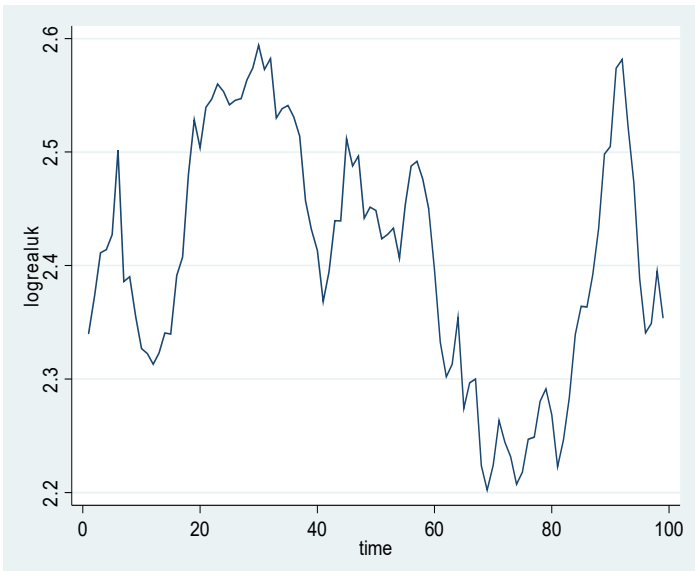

Figure A5. Real exchange rate.

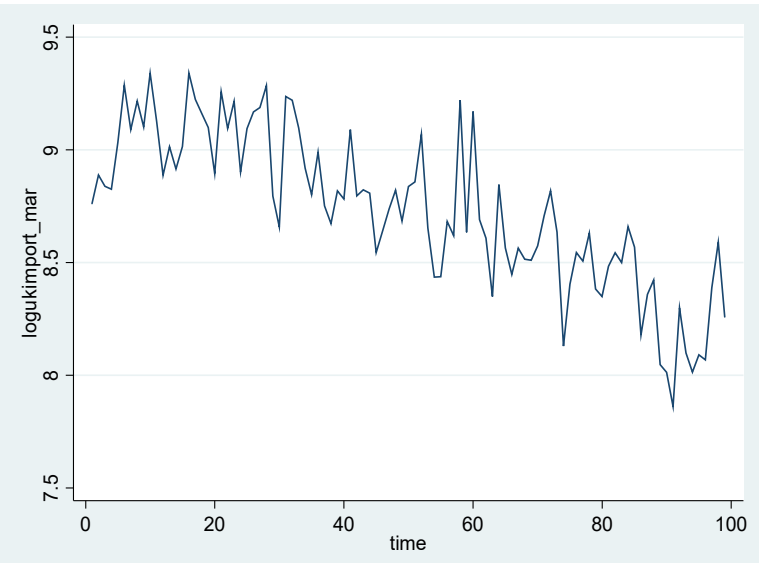

Figure A2. Imports of Norway via maritime transport.

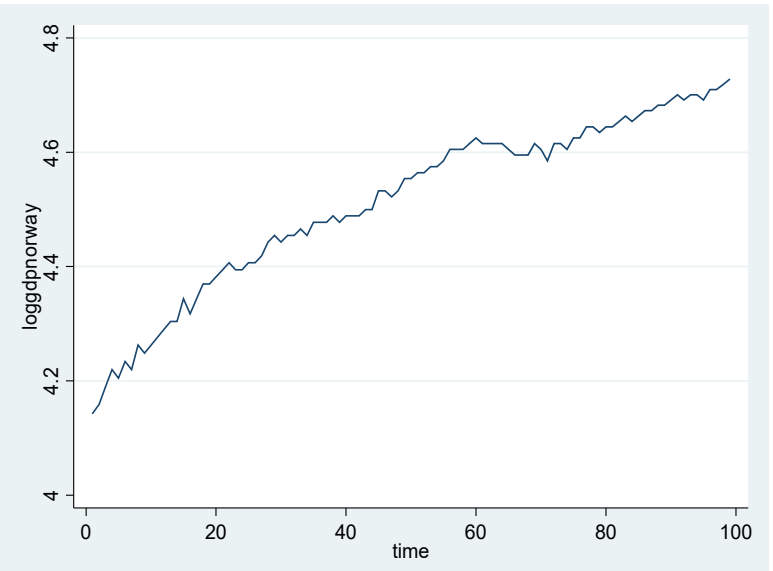

Figure A4. Real income of Norway.

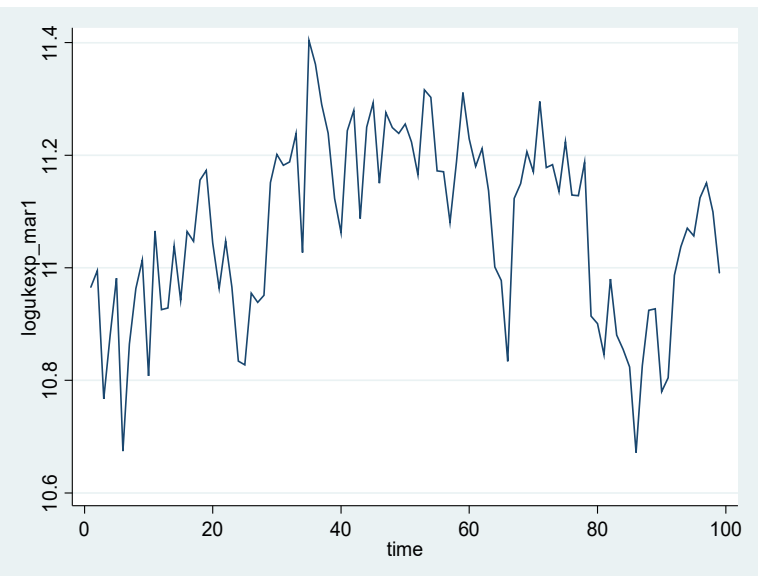

Figure A6. Exports of Norway via maritime transport. 


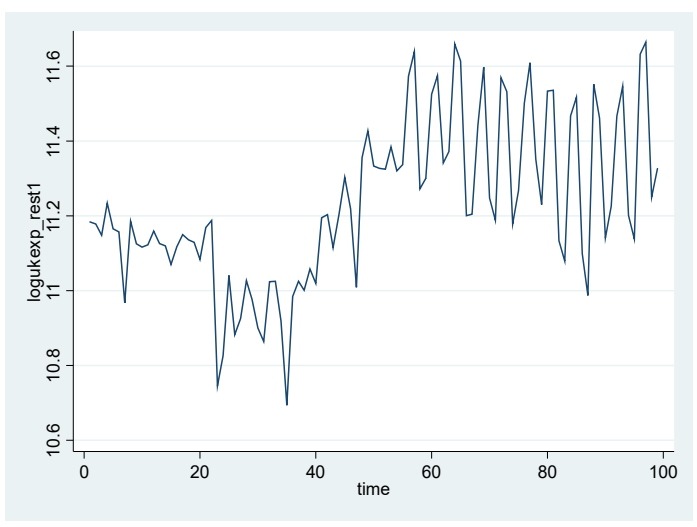

Figure A7. Exports of Norway via other modes.

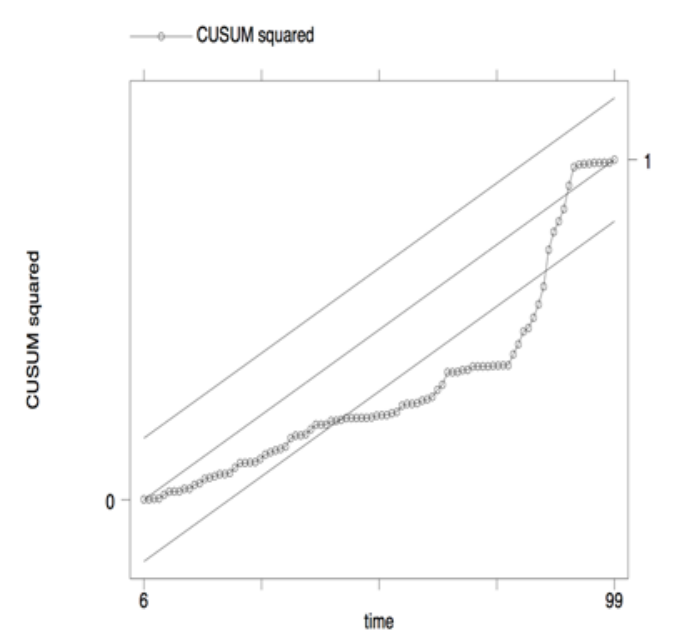

Figure A9. Plot of CUSUM (Model 1). The straight lines

represent critical bounds at a 5 percent significance level.

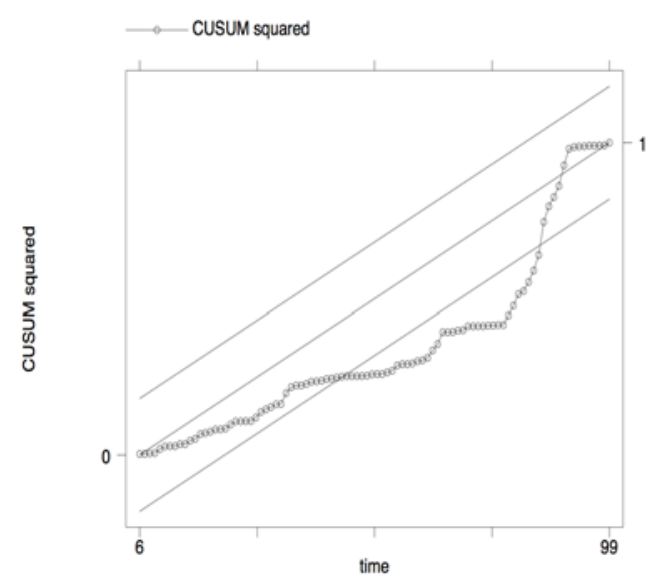

Figure A11. Plot of CUSUM (Model 3).

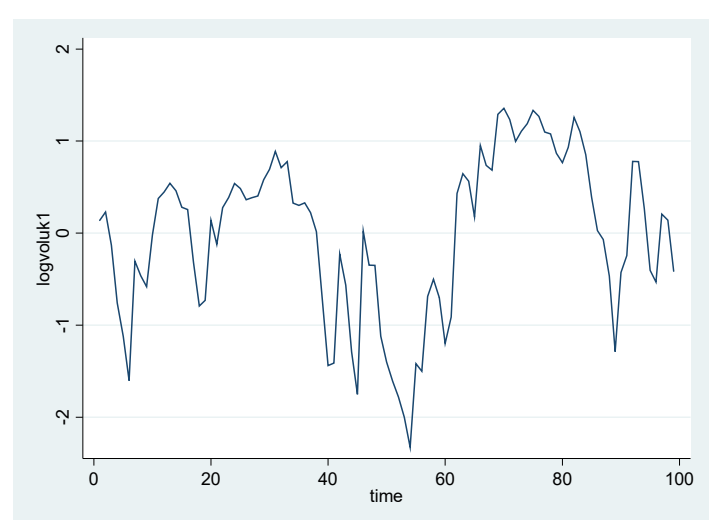

Figure A8. Exchange-rate volatility.

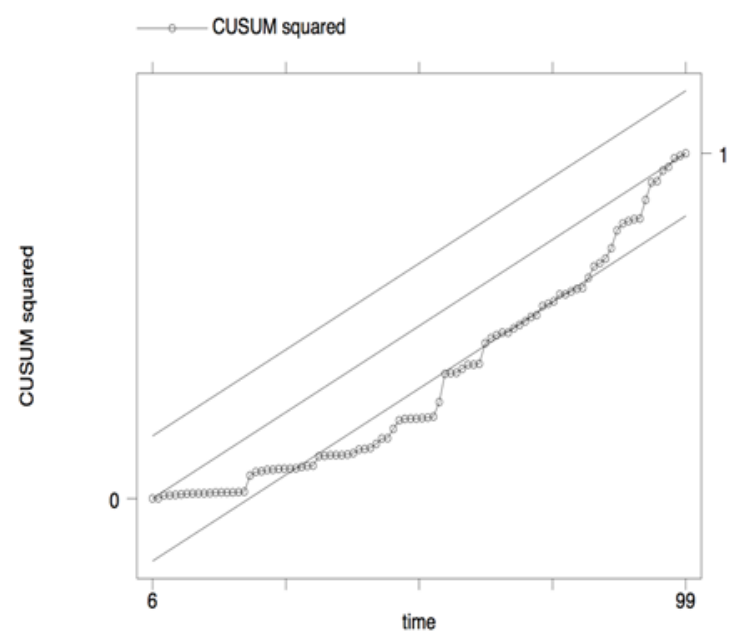

Figure A10. Plot of CUSUM (Model 2).

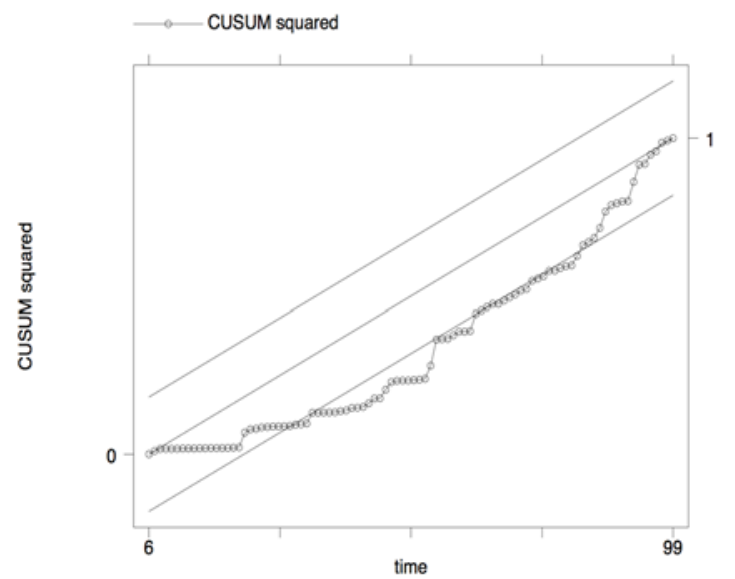

Figure A12. Plot of CUSUM (Model 4). 


\section{Table A1. Critical values for bounds testing}

\begin{tabular}{|c|c|c|c|c|c|c|c|c|c|c|c|c|}
\hline & \multicolumn{6}{|c|}{$F$-test } & \multicolumn{6}{|c|}{$t$-test } \\
\hline & \multicolumn{2}{|c|}{$1 \%$} & \multicolumn{2}{|c|}{$5 \%$} & \multicolumn{2}{|c|}{$10 \%$} & \multicolumn{2}{|c|}{$1 \%$} & \multicolumn{2}{|c|}{$5 \%$} & \multicolumn{2}{|c|}{$10 \%$} \\
\hline & $\begin{array}{l}\text { Lower } \\
\text { bound }\end{array}$ & $\begin{array}{l}\text { Upper } \\
\text { bound }\end{array}$ & $\begin{array}{l}\text { Lower } \\
\text { bound }\end{array}$ & $\begin{array}{l}\text { Upper } \\
\text { bound }\end{array}$ & $\begin{array}{l}\text { Lower } \\
\text { bound }\end{array}$ & $\begin{array}{l}\text { Upper } \\
\text { bound }\end{array}$ & $\begin{array}{l}\text { Lower } \\
\text { bound }\end{array}$ & $\begin{array}{l}\text { Upper } \\
\text { bound }\end{array}$ & $\begin{array}{l}\text { Lower } \\
\text { bound }\end{array}$ & $\begin{array}{l}\text { Upper } \\
\text { bound }\end{array}$ & $\begin{array}{l}\text { Lower } \\
\text { bound }\end{array}$ & $\begin{array}{l}\text { Upper } \\
\text { bound }\end{array}$ \\
\hline Model 1 & 2.45 & 3.52 & 2.86 & 4.01 & 3.74 & 5.06 & -2.57 & -3.66 & -2.86 & -3.99 & -3.43 & -4.60 \\
\hline Model 2 & 2.45 & 3.52 & 2.86 & 4.01 & 3.74 & 5.06 & -2.57 & -3.66 & -2.86 & -3.99 & -3.43 & -4.60 \\
\hline Model 3 & 2.45 & 3.52 & 2.86 & 4.01 & 3.74 & 5.06 & -2.57 & -3.66 & -2.86 & -3.99 & -3.43 & -4.60 \\
\hline Model 4 & 2.45 & 3.52 & 2.86 & 4.01 & 3.74 & 5.06 & -2.57 & -3.66 & -2.86 & -3.99 & -3.42 & -4.60 \\
\hline
\end{tabular}

Note: Critical values from Pesaran et al. (2001). 